\title{
Effect of leaf decomposition stage and water temperature on fragmentation activity of a shredder invertebrate species in lotic ecosystems
}

\author{
Fernanda K. S. P. Navarro' \& José F. Gonçalves Júnior²
}

\author{
1. Departamento de Áreas Acadêmicas, Campus Águas Lindas, Instituto Federal de Educação, Ciência e Tecnologia de Goiás - IFG, $72910-733$ \\ Águas Lindas de Goiás, GO, Brazil. (fbionavarro@gmail.com) \\ 2. Departamento de Ecologia, Universidade de Brasília, Campus Darcy Ribeiro, Asa Norte, 70910-900 Brasília, DF, Brazil.
}

Received 4 June 2016

Accepted 27 December 2016

DOI: $10.1590 / 1678-4766 e 2017017$

\begin{abstract}
The attractiveness of a given leaf detritus to invertebrates depends on the chemical composition, physical structure, stage of microbial colonization and decomposition level. In addition to the leaf detritus quality, water temperature also affects organic matter cycling in aquatic environments. In this context, the objectives of this study were: i) to increase knowledge about the role of invertebrate shredders on fragmenting senescent, conditioned senescent and green leaves of Richeria grandis Vahl. (Phyllanthaceae) under gradual temperature rise and check leaf mass loss; ii) to verify the preference of Phylloicus sp. (Trichoptera) for leaves for larval case production. The experiment I consisted of three treatments with different water temperatures: $20^{\circ} \mathrm{C}$, $24^{\circ} \mathrm{C}$ and $28^{\circ} \mathrm{C}$. In the experiment II, we added 10 discs of green leaves of $R$. grandis and two shredder invertebrates (Phylloicus sp.) to each aquarium. Leaf mass loss in the presence or absence of fragmentation was not significantly influenced by differences in the intraspecific quality of the detritus or temperature. Intraspecific quality of resources mixed with green leaves can lead to increased contact of phenolic content on senescent leaves, leading to a similarity in food exploitation by invertebrates. However, the production of larval cases by Phylloicus sp. seems to be dependent on the resistance presented by the resource rather than the phenolic content, thus leading the shredders to use significantly more senescent detritus, regardless temperature.
\end{abstract}

KEYWORDS. Microcosms, chemical composition, Phylloicus sp., warming of water.

RESUMO. Efeito do estágio de decomposição foliar e temperatura da água sobre a atividade de fragmentação de uma espécie de invertebrado fragmentador em ecossistemas lóticos. A atratividade de um determinado detrito foliar pelos invertebrados depende da composição química, estrutura física, estágio de colonização microbiana e nível de degradação do detrito. Além da qualidade do detrito foliar, a temperatura da água tem sido outro fator que pode levar a variações na velocidade da ciclagem de matéria orgânica em ambientes aquáticos. Os objetivos deste estudo foram: i) ampliar os conhecimentos acerca do papel dos invertebrados fragmentadores sobre a atividade de fragmentação de folhas senescentes, senescentes condicionadas e verdes de Richeria grandis Vahl. (Phyllanthaceae) sob elevações graduais de temperatura e verificar as possíveis consequências sobre a perda de massa foliar; ii) verificar a preferência de recurso foliar para a construção de casulo pelo invertebrado fragmentador Phylloicus sp. (Trichoptera). O experimento I foi constituído de três tratamentos que se diferiram apenas na temperatura da água: Tratamento $1: 20^{\circ} \mathrm{C}$, Tratamento $2: 24^{\circ} \mathrm{C}$, Tratamento $3: 28^{\circ} \mathrm{C}$. $\mathrm{O}$ experimento II se diferiu do I pelo acréscimo de dez discos de folhas verdes de $R$. grandis e dois invertebrados (Phylloicus sp.) em cada aquário. A perda de massa foliar na presença ou ausência de atividade de fragmentação não foi influenciada significativamente por diferenças na qualidade intraespecífica do detrito e ou por diferenças na temperatura. A qualidade intraespecífica de recursos misturados com folhas verdes pode levar ao aumento do contato de conteúdos fenólicos sobre folhas senescentes, levando a uma similaridade na exploração alimentar pelos invertebrados. No entanto, a construção de casulos pelos Phylloicus sp. parece ser dependente da resistência apresentada pelo recurso e não do conteúdo fenólico, levando assim os fragmentadores a utilizarem significativamente uma maior quantidade de detritos senescentes, independente da temperatura.

PALAVRAS-CHAVE. Microcosmos, composição química, Phylloicus sp., aquecimento da água.

Invertebrate shredders have an important role in processing organic matter in the aquatic environment, releasing nutrients that can be used by other organisms (GRAÇA, 2001; TANAKA et al., 2006). The contribution of shredders is well known in temperate regions, although the importance of these organisms in the leaf decomposition process in tropical streams has also been investigated (Moretti et al., 2009; NAVArro et al., 2013). Phylloicus sp. shredder larvae (Trichoptera) are invertebrates found among leaves submerged in lotic environments. Foliar fragments are used for food and as raw materials for building back- ventrally case by Phylloicus species, thus contributing to the fragmentation process within the leaf aquatic chain detrital (Wiggins, 2004; WANTZEN \& WAGNER, 2006).

The attractiveness of a given leaf detritus for invertebrates depends on the chemical composition, physical structure, stage of microbial colonization and decomposition level of the detritus, which can vary with the exposure time in the aquatic environment (LigEIRo et al., 2010). Most studies in tropical streams has sought to expand the knowledge about the influence of interspecific variation in the quality of senescent detritus on the fragmentation by invertebrates, 
either for food or for producing larval case (MoRETTI et al., 2009; NaVArro et al., 2013). Nevertheless, several types of detritus, such as woody material, reproductive organs of plants, green leaves may contain a higher concentration of nitrogen and phenolic compounds (DAY \& MonK, 1977; CAMPBEll et al., 1992), and may also represent a source of energy in aquatic ecosystems. In this way, although research in temperate environments has indicated the participation of green leaves in leaf decomposition process (Gosz et al., 1972; Risley \& Crossley, 1988; Kochi et al., 2010), their importance in tropical streams is still understudied.

In addition to the influence of the leaf detritus quality, water temperature is another factor influencing the organic matter decomposition rate in aquatic environments. Rising temperature can promote changes in the abundance and fragmentation activity of shredders (GONZALEZ \& GRAÇA, 2003; AzeVEdo-Pereira et al., 2006), accelerating their metabolism, which lead to a higher consumption, and leaching of soluble compounds (Chergui \& PATTEe, 1990), and also accelerate microbial growth on the leaf resource in lotic ecosystems (CARPENTER \& ADAMS, 1979). Thus, an increase in temperature can have serious consequences, such as physiological changes of different organisms, local species extinction, changes in competitive interactions and ecological processes, exponential increase in metabolic rates (Brown et al., 2004; Mooney et al., 2009). These effects may reflect the individual, population, or communities levels, driving the leaf decomposition process and thus the functioning of stream ecosystems (Villanueva et al., 2011).

This study aimed to (i) assess the fragmentation activity of Phylloicus sp. on senescent, conditioned senescent and green leaves of Richeria grandis Vahl. (Phyllanthaceae) under gradual temperature rise; (ii) check the preference of Phylloicus sp. for leaf resources for larval case production. Assuming that rising temperature accelerate the loss of soluble compounds from leaf detritus and enhance the microbial activity on these resources, and that the fragmentation activity of Phylloicus sp. is influenced by the quality of leaf detritus and temperature, we hypothesized that: (1) the decomposition degree of leaf detritus influences the leaf mass loss (experiments I and II); (2) the leaf mass loss in the absence of fragmentation is positively related to rising temperature (experiment I); (3) the temperature rising enhances leaf mass loss through fragmentation due to the increased metabolism of invertebrates (experiment II); and (4) the resource type affects the preference for detritus for producing larval cases, regardless temperature (experiment II).

\section{MATERIAL AND METHODS}

Collection procedures. Phylloicus sp. individuals were collected by active search at the Capetinga Stream (15'57'32”S, 4756'33”'W, Agua Limpa Farm of the Universidade de Brasília, Federal District) in July 2012. It is a new species not yet described. Specimens were taken to the laboratory in cool boxes with stream water. At the laboratory, invertebrates in their leaf larval cases were acclimated for 24 hours in $60 \mathrm{~L}$-aquaria, with water and fine gravel bottom collected from the stream. Aquaria were continuously aerated during the acclimation period.

Conditioned senescent detritus (leaves of Richeria grandis, popular names: Santa-Rita, or Pau-de-Santa-Rita) used in the experiments were submerged in litter bags $(0.5$ $\mathrm{mm}$ mesh size, about $15 \mathrm{~g}$ of detritus) for 7 days for microbial conditioning at the Capetinga Stream (Conditioning). The chemical composition of senescent leaves of Richeria grandis is as follows: $7 \% \mathrm{~g} \mathrm{~g}^{-1}$ of polyphenols; $400 \mathrm{~g}$ hardness; $29 \%$ $\mathrm{g}^{-1}$ lignin and $21 \% \mathrm{~g} \mathrm{~g}^{-1}$ cellulose (NAVARro et al., 2013). It is an abundant plant species found in riparian zones of the Cerrado Biome and exploited by Phylloicus sp. according to NAVARro et al. (2013) and BAmBI et al. (2016).

Experimental procedures. The experiment I consisted of three treatments (one aquarium for treatment) with different water temperatures: Treatment $1: 20^{\circ} \mathrm{C}$, Treatment $2: 24^{\circ} \mathrm{C}$, Treatment $3: 28^{\circ} \mathrm{C}$. The lowest threshold of this gradient was set according to the average temperature found in the Capetinga Stream (F. A. Bezerra, unpubl. data) and the other temperature levels simulated the effect of global warming. Each aquarium $(60 \mathrm{~L})$ was provided with 18 leaf discs (nine discs of senescent leaves and nine discs of conditioned senescent leaves) of R. grandis (Fig. 1).

The experiment II also consisted of three treatments with different water temperatures: Treatment $1: 20^{\circ} \mathrm{C}$, Treatment $2: 24^{\circ} \mathrm{C}$, Treatment $3: 28^{\circ} \mathrm{C}$. To each aquarium, we added two invertebrates (Phylloicus sp.) without their leaf larval cases and 27 leaf discs (nine discs of senescent leaves, nine discs of conditioned senescent leaves and nine discs of green leaves) of $R$. grandis. Each type of resource was arranged into a single set, which was placed at distinct positions inside the aquarium (Fig. 1).

In both experiments, the temperature at each aquarium was maintained by automatic thermostats, oxygenation was provided by aerators and a submersion pump was used to simulate lotic flow. Water parameters (dissolved oxygen, $\mathrm{pH})$ were measured daily.

Percentage of leaf mass loss. In each experiment, leaf discs were cut with a cork borer $(1.8 \mathrm{~cm}$ diameter), freeze-dried in a lyophilizer and weighed on a precision scale $(0.00001 \mathrm{~g})$ to determine the initial dry weight. Subsequently, the nine discs of each detritus type in each aquarium (same leaf species but distinct decomposition stage) were grouped into three sets of three discs (average and standard deviation was calculated for each set of three discs). These discs were attached onto the aquarium substrate with the aid of pins and rubber fragments of varied colorations in order to facilitate their identification.

After seven days of each experiment (sufficient time to verify an intense exploration activity on the leaf resources, NAVARRO et al., 2013), leaf discs from each treatment were freeze-dried in a lyophilizer and weighed on a precision scale $(0.00001 \mathrm{~g})$ to obtain the final dry weight. Leaf mass loss (LML) was determined for each treatment by the difference between initial final dry weight of the discs. In the experiment 


\section{Experiment I}

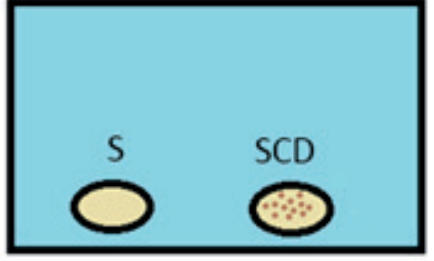

$20^{\circ} \mathrm{C}$

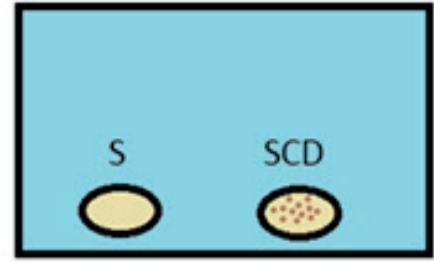

$24^{\circ} \mathrm{C}$

Experiment II

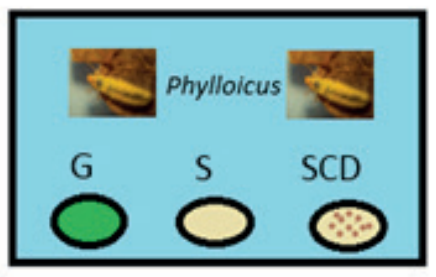

$20^{\circ} \mathrm{C}$

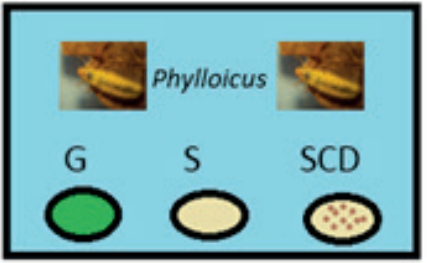

$24^{\circ} \mathrm{C}$

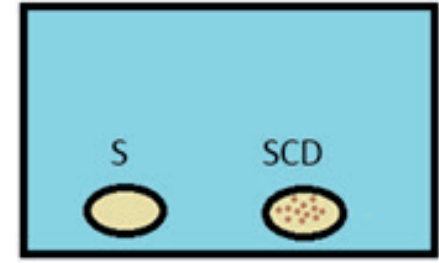

$28^{\circ} \mathrm{C}$

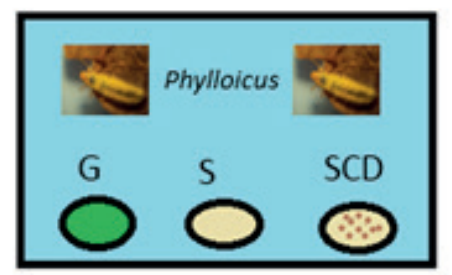

$28^{\circ} \mathrm{C}$

Fig. 1. Schematic representation of the experimental design of the present study. Experiment I: nine discs of senescent (S) and nine discs of conditioned senescent (SCD) wastes were used in each aquarium in the absence of shredder invertebrates. Experiment II: nine discs of senescent (S), nine discs of conditioned senescent (SCD) and nine discs of green detritus (G) were used in each aquarium in the presence of shredded invertebrates (Phylloicus sp.).

II, larval cases from each treatment were freeze-dried and weighed to quantify the discs used to construct larval cases, and the green and senescent detritus were weighed separately.

As the temperature did not statistically influence LML in the experiments I and II ( $p>0.05)$, we considered nine replications for each type of detritus (three replications per tank in three aquariums $=$ nine replications).

Statistical analysis. In experiment I and II, LML (response variable) was tested against the type of detritus, the temperature gradient and the interaction between these two factors (explanatory variables of higher hierarchical level) through a split-plot analysis of variance (SPANOVA) (CRAWLER, 2007); each aquarium was included as an explanatory variable of lower hierarchical level. Furthermore, in the experiment II, LML of different detritus for the construction of larval case by Phylloicus sp. was also tested by the same statistical test mentioned above. Data normality was tested by the Kolmogorov-Smirnov; when necessary, data were log-transformed (MASSEY JR, 1951). All analyses were performed using the $\mathrm{R}$ program (vegan package, OKSANEN et al., 2008; R Development Core Team, 2011).

\section{RESULTS}

Experiment I. The percentage of leaf mass loss (LML) in the absence of fragmentation by Phylloicus sp. of senescent detritus of $R$. grandis was not significantly influenced by the presence of leaf conditioning in the stream (SPANOVA, $\mathrm{F}_{10,1}=0.1, \mathrm{p}=0.778$ ) and the temperature gradient $\left(\mathrm{F}_{10,2}=2.4, \mathrm{p}=0.144\right.$, Tab. I).

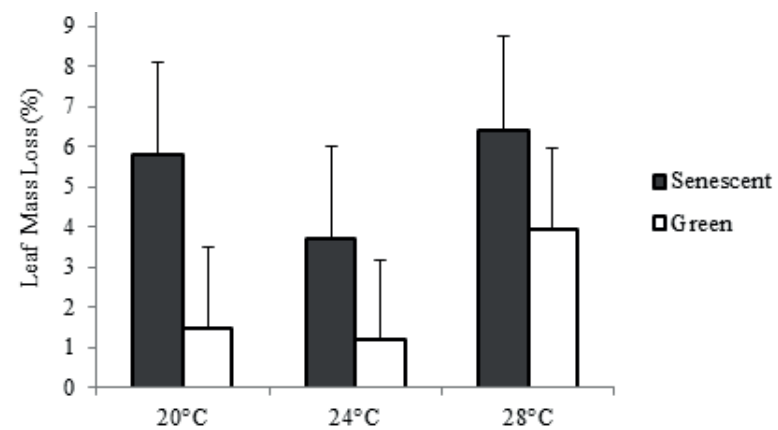

Fig. 2. Mean values and standard error of leaf mass loss (LML) of senescent (senescent plus conditioned senescent, due to the absence of visual distinction by coloration) and green detritus for larval case production by Phylloicus sp. in the different water temperature treatments at Capetinga Stream, Água Limpa Farm, Brasília, Brazil.

Experiment II. The type of the leaf resource (SPANOVA, $\mathrm{F}_{16,2}=2.8, \mathrm{p}=0.093$ ) and temperature (SPANOVA, $\mathrm{F}_{16,2}=1.7, \mathrm{p}=0.219$ ) showed no significant change in the fragmentation process by Phylloicus sp. for feeding (Tab. I). However, for larval case construction, the invertebrate shredders had significantly greater preference for senescent detritus (SPANOVA, $\mathrm{F}_{10,1}=5.8, \mathrm{p}=0.035$ ), regardless temperature (SPANOVA, $\mathrm{F}_{10,2}=1.5, \mathrm{p}=0.258$, Fig. 2).

\section{DISCUSSION}

Leaf mass loss (LML) vs. detritus quality. The lack of significant difference in LML between the different 
Tab. I. Mean values and standard error of leaf mass loss (LML, \%) of senescent (S), conditioned senescent (SCD) and green (G) leaf litter (Richeria grandis Vahl.) at different temperatures, Capetinga Stream, Água Limpa Farm, Brasília, Brazil. Experiment I: Senescent (S) and conditioned senescent (SCD) detritus were used in the absence of shredder invertebrates. Experiment II: Senescent (S), conditioned senescent (SCD) and green detritus were used in the presence of shredded invertebrates.

\begin{tabular}{|c|c|c|c|c|c|}
\hline & \multicolumn{2}{|c|}{ Experiment I } & \multicolumn{3}{|c|}{ Experiment II } \\
\hline & $\mathrm{S}$ & SCD & $\mathrm{S}$ & SCD & $G$ \\
\hline $20^{\circ} \mathrm{C}$ & $28.33 \pm 2.27$ & $17.22 \pm 1.70$ & $60.89 \pm 6.45$ & $39.86 \pm 10.29$ & $61.91 \pm 15.32$ \\
\hline $24^{\circ} \mathrm{C}$ & $25.57 \pm 2.41$ & $25.44 \pm 4.83$ & $47.71 \pm 9.28$ & $29.94 \pm 8.70$ & $40.70 \pm 11.45$ \\
\hline $28^{\circ} \mathrm{C}$ & $26.83 \pm 2.31$ & $35.3 \pm 8.33$ & $60.60 \pm 16.33$ & $40.49 \pm 8.63$ & $59.48 \pm 5.97$ \\
\hline
\end{tabular}

detritus types on experiments I and II can be related to the quality of detritus of $R$. grandis, which is a species of good quality. Its leaves have low concentrations of lignin $(28.9 \%$ $\left.\mathrm{g}^{-1}\right)$ and cellulose $\left(20.8 \% \mathrm{~g}^{-1}\right)$ as compared to other plants of the Brazilian Cerrado, such as Inga laurina $(43.56 \%$ $\mathrm{g}^{-1}$ lignin and $29.11 \% \mathrm{~g}^{-1}$ cellulose; NAVARro et al., 2013). Thus, good quality detritus (low concentration of refractory compounds ex. lignin and cellulose) can lead to a similarity in LML of detritus, although they are in different stages of decomposition. The feeding preference of shredders can be associated with different properties of the leaf, like nitrogen content, pre-conditioning by microorganisms, and presence of secondary compounds that determine the palatability of detritus (Webster \& Benfield, 1986; GraÇA, 2001). Therefore, the 7 day-acclimation period in the natural environment (instream) may not have been sufficient to increase significantly the microbial community onto the conditioned senescent detritus and hence their palatability for invertebrate shredders. Moreover, Gomes et al. (2016) found that leaching of $R$. grandis may be longer than 7 days. On the other hand, microbial colonization is usually complete within the first 2 weeks, which may enhance the activity of microbial enzymes on lignin/cellulose compounds, nutritional and energy value of the organic matter (GRAÇA et al., 1993; ABELHo, 2001; GonÇALVES et al., 2006; NAVARRo et al., 2013).

The presence of green leaves, with greater ability to release phenolic compounds, may have contributed to delay the increase in microbial biomass and activity on the conditioned senescent detritus and thereby reduce their palatability (LAWsOn et al., 1984; GRAÇA et al., 1993). The mixture of green and senescent leaves in the experiment II may lead to an increased quality in the invertebrate shredders diet due to the increased intake of $\mathrm{N}$ (green leaves) combined with a reduced intake of phenolic compounds (senescent leaves). According to some studies, green leaves usually contain more N (DAY \& MoNK, 1977) and phenolic content than senescent leaves (CAMPBELL et al., 1992). Other studies have reported this improvement in the diet resulting from the mixture of food items (green and senescent leaves), which may lead to an improved development of detritivorous species, like Phylloicus sp. (Freeland \& JANZen, 1974; Pennings et al., 1993; Bernays et al., 1994).

Although other studies have reported a greater preference of Phylloicus sp. for detritus with increased concentration of phenolic compounds in the production of their larval cases (RINCón \& MARTINEZ, 2006; MoRetTi et al.,
2009), given their ability to protect detritus against microbial activity (CAMPbell \& Fuchshuber, 1995; Salusso, 2000), we did not found this preference in the present study. Possibly, a greater hardness presented by senescent leaves, despite the lower content of phenolic compounds, allowed these resources to be fragmented by Phylloicus sp. for production of larval cases. However, the fragmentation activity on green leaves was mainly destined to feed the shredders, for enriching the nutritional quality of the diet (KocHI et al., 2010).

Leaf mass loss (LML) vs. temperature rise. Studies have reported that increased temperature may affect leaf decomposition, by intensifying the leaching of secondary compounds (Chergui \& Pattee, 1990; Ardón \& Pringle, 2008), and increasing microbial activity (CARPENTER \& Adams, 1979; Irons et al., 1994; Abelho et al., 2005; BERGFur et al., 2007). However, in the present study the temperature was not able to influence the LML of the different types of foliar detritus. Possibly, the stage of leaf decomposition influenced the individual properties of the leaf resource (for example, lignin, cellulose and polyphenol) (TAYLOR \& Bärlocher, 1996; GoMes et al., 2016).

Some studies addressed the association between rising temperature and increased metabolism of certain organisms (DANG et al., 2009) and increased leaf decomposition rate mediated by detritivorous in tropical streams of Australia (BOyero et al., 2014). Conversely, in this study there was no relationship between rising temperature and detritus fragmentation by invertebrates (experiment II). This may suggest that Phylloicus sp. subjected to detritus of better nutritional quality, that is a mixture of senescent, conditioned senescent and green leaves (FreEland \& JANZEN, 1974; Pennings et al., 1993; Bernays et al., 1994; Kochi et al., 2010), may have increased their efficiency of nutrient assimilation independent of the temperature variation.

Leaf mass loss seems to be dependent on its properties (physical, chemical and nutritional characteristics) linked to the different decomposition stages of a species (senescent, conditioned senescent and green leaves). In this way, rising temperature did not accelerate the leaching process in resources of the studied plant species detritus ( $R$. grandis) and did not intensify the fragmentation process by Phylloicus sp. In addition, our results suggest that invertebrate shredders can take advantage from the mixture of $\mathrm{N}$-rich resources (green leaves) and detritus with higher hardness (senescent leaves) that are more suitable to the production of larval cases. This may favors the magnification of the nutritional 
value of the diet without an increased intake of detritus, thereby contributing to further development, protection and survival of these shredders, which play an important role in the fragmentation step of the leaf decomposition process.

Acknowledgements. We are grateful to PROCAD-NF/CAPES (\#173/2010), PELD/CNPq (\#558233/2009-0), FAPEMIG (APQ-0027412), Programa de Pós-Graduação em Ciências Biológicas/Unimontes, and Scholarship of Graduation (PROIC/2012-Recém-Doutor/DPP) and founds of Universidade de Brasília (DPP; \#121366/2011) for the financial support. Also, we thank to the REUNI Program for the PhD Scholarship granted to senior author (\#07/2011). Finally, we would like to express our special gratitude to all evening students from the discipline Physical Environment and Ecosystems-2012.

\section{REFERENCES}

Abelho, M. 2001. From litterfall to breakdown in streams: a review. The Scientific World 17:656-80.

Abelho, M.; Cresssa, C. \& Graça, M. A. S. 2005. Microbial biomass, respiration, and decomposition of Hura crepitans L. (Euphorbiaceae) leaves in a tropical stream. Biotropica 37:397-402.

Ardón, M. \& Pringle, C. M. 2008. Do secondary compounds inhibit microbialand insect-mediated leaf breakdown in a tropical rainforest stream, Costa Rica? Oecologia 155:311-323.

Azevedo-Pereira, H.; González, J. \& GraÇA, M. A. S. 2006. Life history of Lepidostoma hirtum in an Iberian stream and its role on organic matter processing. Hydrobiologia 559:183-192.

Bambi, P.; Rezende, R. S.; Feio, M. J.; Leite, G. F. M.; Alvim, E. A. C. C.; Quintão, J. M. B.; Bezerra, F. A. \& Gonçalves, J. F. JR. 2016. Temporal and Spatial Patterns in Inputs and Stock of Organic Matter in Savannah Streams of Central Brazil. Ecosystems 20: (in press). DOI: $10.1007 / \mathrm{s} 10021-016-0058-\mathrm{z}$

Bergfur, J.; Johnson, R. K.; SANDin, L. \& GoEdKoop, W. 2007. Assessing ecological integrity of boreal streams: a comparison of structural and functional responses. Fundamental and Applied Limnology 168:113-125

Bernays, E. A.; Bright, K. L.; Gonzalez, N. \& Angel, J. 1994. Dietary mixing in a generalist herbivore: tests of two hypotheses. Ecology 75:1997-2006.

Boyero, L.; Cardinale, B. J.; Bastian, M. \& Pearson, R. G. 2014. Biotic vs. abiotic control of decomposition: A comparison of the effects of simulated extinctions and changes in temperature. PLoS ONE 9(1):e87426. doi:10.1371/journal.pone.0087426.

Brown, J. H.; Gilloly, J. F.; Allen, A. P.; Savage, V. M. \& West, G. B. 2004. Toward a metabolic theory of ecology. Ecology 85:1771-1789.

Campbell, I. C. \& Fuchshuber, L. 1995. Polyphenols, condensed tannins, and processing rates of tropical andtemperate leaves in an Australian stream. Journal of the North American Benthological Society 14:174-182.

Campbell, I. C.; James, K. R.; Hart, B. T. \& Devereaux, A. 1992. Allochthonous coarse particulate organic material in forest and pasture reaches of two south-eastern Australian streams. II. Litter processing. Freshwater Biology 27:353-365.

CARPENTER, S. R. \& ADAMS, M. S. 1979. Effects of nutrients and temperature on decomposition of Myriophyllumspicatum L. in a hardwater eutrophic lake. Limnology and Oceanography 24:520-528.

Chergui, H. \& Pattee, E. 1990. The influence of season on the breakdown of submerged leaves. Archiv für Hydrobiologie 120:1-12.

Crawler, M. J. 2007. The R Book. London, John Wiley \& Sons. 942p.

Dang, C. K.; Schindler, M.; Chauvet, E. \& Gessner, M. O. 2009. Temperature oscillation coupled with fungal community shifts can modulate warming effects on litter decomposition. Ecology 90(1):122131.

DAY, F. P. \& MonK, C. D. 1977. Seasonal nutrient dynamics in the vegetation on a southern Appalachian watershed. American Journal of Botany 64:1126-1139.

FREELAND, W. J. \& JANZEN, D. H. 1974. Strategies in herbivory by mammals: the role of plant secondary compounds. The American Naturalist 108:269-289.
Gomes, P. P.; MedeIros, A. O. \& GonçALVEs, J. F. JR. 2016. The replacement of native plants by exotic species may affect the colonization and reproduction of aquatic hyphomycetes. Limnologica 59:124-130

Gonçalves Jr., F. J.; França, J. S.; Medeiros, A. O.; Rosa, C. A. \& CALLISTO, M. 2006. Leaf breakdown in a tropical stream. International Review Hydrobiology 91:164-177.

González, J. M. \& GraçA, M. A. S. 2003. Conversion of leaf litter to secondary production by a shredding caddis-fly. Freshwater Biology 48:1578-1592.

Gosz J. R.; Likens, G. E. \& Bormann F. H. 1972. Nutrient content of litter fall on the Hubbard Brook Experimental Forest, New Hampshire. Ecology 53:769-784.

GraÇA, M. A. S. 2001. The role of invertebrates on leaf litter decomposition in streams - a review. International Review Hydrobiology 86:383-393.

Graça, M. A. S.; Maltby, L. \& Calow, P. 1993. Importance of fungi in the diet of Gammarus pulex and Asellus aquaticus I: feeding strategies. Oecologia 93:139-144.

Irons, J. G.; Oswood, M. W.; Scout, R. J. \& Pringle, C. M. 1994. Latitudinal patterns in leaf litter breakdown: is temperature really important? Freshwater Biology 32:401-411.

Kochi, K.; Kagaya, T. \& Kusumoto, D. 2010. Does mixing of senescent and green leaves result in nonadditive effects on leaf decomposition. Journal of the North American Benthological Society 29(2):454-464.

Lawson, D. L.; Klug, M. J. \& Merritt, R. W. 1984. The influence of the physical, chemical, and microbiological characteristics of decomposing leaves on the growth of the detritivoreTipulaabdominalis (Diptera: Tipulidae). Canadian Journal of Zoology 62:2339-2343.

Ligeiro, R.; Melo, A. S. \& Callisto, M. 2010. Spatial scale and the diversity of macroinvertebrates in a Neotropical catchment. Freshwater Biology 55:424-435.

Massey, F. J. JR. 1951. The Kolmogorov-Smirnov test for goodness of fit. Journal of the American Statistical Association 46:68-78

Mooney, H.; Larigauderie, A.; Cesario, M.; ElmQuist, T.; HoeghGuldberg, O.; Lavorel, S.; G. Mace, M.; Palmer, M.; Scholes, S. \& YAHARA, T. 2009. Biodiversity, climate change, and ecosystem services. Current Opinion in Environmental Sustainability 1:46-54.

Moretti, M. S.; Loyola, R. D.; Becke, B. \& Callisto, M. 2009. Leaf abundance and phenolic concentrations codetermine the selection of case-building materials by Phylloicus sp. (Trichoptera, Calamoceratidae). Hydrobiologia 630(1):199-206.

Navarro, F. K. S. P.; Rezende, R. S. \& Gonçalves J. F.JR. 2013. Experimental assessment of temperature increase and presence of predator carcass changing the response of invertebrate shredders. Biota Neotropica 13. Available at $<\mathrm{http} / / / \mathrm{www}$.biotaneotropica.org. br/v13n4/en/abstract?article+bn00313042013>.

Oksanen, A. J.; Kindt, R.; Legendre, P.; O’Hara, R. B.; Simpson, G. L.; Stevens, M. H. H. \& WaGner, H. 2008. Vegan: community ecology package. $\mathrm{R}$ package version $1.17-0$.

Pennings, S. C.; Nadeau, M. T. \& Paul, V. J. 1993. Selectivity and growth of the generalist herbivore Dolabella auricularia feeding upon complementary resources. Ecology 74:879-890.

R Development Core Team. 2011. R: A language and environment for statistical computing. Vienna, R Foundation for Statistical Computing. Avalaible at $<\mathrm{http}: / /$ www.R-project.org $>$.

RinCón, J. \& MARTÍNEZ, I. 2006. Food quality and feeding preferences of Phylloicus sp. (Trichoptera: Calamoceratidae). Journal of the North American Benthological Society 25:209-215.

Risley, L. \& Crossley, D. A. 1988. Herbivore-caused greenfall in the southern Appalachians. Ecology 69:1118-1127.

Salusso, M. M. 2000. Biodegradation of subtropical forest woods from north-west Argentina by Pleurotus laciniatocrenatus. New Zealand Journal of Botany 38:721-724.

TANAKA, M. O.; RibaS, A. C. A. \& SouZA, A. L. T. 2006. Macroinvertebrate succession during leaf litter breakdown in a perennial karstic river in Western Brazil. Hydrobiologia 568(1):493-498. doi.org/10.1007/ s10750-006-0195-z.

TAYLOR, B. R. \& Bärlocher, F. 1996. Variable effects of air drying on leaching losses from tree leaf litter. Hydrobiologia 325:173-182.

Villanueva, V. D.; Albariño, R. \& CANHOTO, C. 2011. Detritivores feeding on poor quality food are more sensitive to increased temperatures. Hydrobiologia 678:155-165. 
WANTZEN, K. M. \& WAGNER, R. 2006. Detritus processing by invertebrate shredders: a neotropical-temperate comparison. Journal of the North American Benthological Society 25:214-230.

Webster, J. R. \& Benfield, E. F. 1986. Vascular plant breakdown in freshwater ecosystems. Annual Review of Ecology and Systematics 17:567-594.

Wiggins, G. B. 2004. Caddisflies, the underwater architects. Toronto, University of Toronto Press. 292p 